\title{
MICHAEL \\ Shame, Justice, and \\ Decolonization: A Reply to Catherine Lu
}

\begin{abstract}
This paper discusses two possible difficulties with Catherine Lu's powerful analysis of the moral response to our shared history of colonial evil; both of these difficulties stem from the rightful place of shame in that moral response. The first difficulty focuses on efficacy: existing states may be better motivated by shame at the past than by a shared duty to bring about a just future. The second focuses on equity: it is, at the very least, possible that shame over past misdeeds ought to be brought into the conversation about present duties, in a manner more robust than Lu's analysis allows.
\end{abstract}

Keywords: justice, colonialism, equity, decolonization, shame

\section{Introduction}

I want to start my remarks with a note of sincere thanks: I have learned an exceptional amount from Catherine Lu's Justice and Reconciliation in World Politics. I've learned about the history of colonialism - Lu is exceptionally learned about the history of colonialism as a practice - but I've also learned a great deal about how we might understand the moral legacies left by those practices in the present. In the end, I think her chosen alterations to international law - and to the morality undergirding that law - are ones I might end up endorsing. But I confess to being left with a certain disquiet after having read her book; I can't help but feel that there are some significant moral costs to the alterations she recommends. This paper is my attempt at figuring out the source of my disquiet.

I should note two things, by way of introduction. The first is that the very most I am doing in this paper is to identify some costs of Lu's vision; even if I am right - and I'm not confident I am - the most that I've done is to show what costs that vision entails. It's entirely possible that the costs of the contrary, statist, vision are even greater. The second thing I should note is that I'm going to, by necessity, focus on only a small part of Lu's book; I'll be looking at the change from interactional and statist visions of justice to the structural and pluralist vision she recommends. I'm therefore going to have to pass over in silence some of the most insightful aspects of her work - including her analysis of colonialism and alienation.

So: on Lu's vision, a fruitful way forward in overcoming thelegacy of colonialism would involve the alteration of two implicit cornerstones of the current vision. 
We should move from a transactional account, on which some agent has done a wrong thing to some other agent, to a structural model, on which colonialism rests not on particular harms as ascribed to particular agents, but to a complex and multi-faceted network of agents and norms. We are to move, as it were, 'beyond victims and perpetrators' (Lu, 2017: 21) to a more nuanced and accurate vision of how injustice is produced. We should also, as part of this structural change, move from a statist vision, on which the agents charged with both the wrong and the duty of rectification are states, to a more pluralistic vision, on which any number of agents bear the obligation to overcome the scars left of the world by colonialism.

There are enormous virtues to these moves, and Lu describes these virtues well. What worries me, though, are the ways in which these moves might make it more difficult to assign particular duties right now to particular agents. I have two specific worries here, which might be called the worry about efficiency and the worry about equity. The first worry asks us how we ascribe duties to agents in a manner that gives us some assurance that the duties will be acted upon. The second asks us whether we have ascribed these particular duties in a way that reflects morally relevant criteria. I'll go over these worries in order.

\section{Efficiency: Moral Motivation and Shame}

When I worry about efficiency, what I'm worried about is the reasons people have to do what justice demands. The structural vision, I think, requires the following sort of moral motivation: while I am not a particular agent who has done wrong, I am in a position to eliminate the current legacy of past evil. I can, as it were, make the world right. This is, I think, a forward-looking duty. While history is relevant, it is only relevant in explaining why I (right now) am a beneficiary of wrongdoing, or why I have been granted the power required to make the world better. The real key is that I can make the world more just going forward.

This isn't an implausible form of motivation - people have been motivated by less. But it's thin, in comparison to another sort of motivation: that which comes from shame. I understand shame here as being a sense of personal wrongdoing, in which I experience unhappiness at having done something wrong - at having been a perpetrator, in an interaction that made someone else a victim. I think shame is often a more powerful motivator than the abstract notion of a duty to build just institutions - and that this is true even if that shame is, perhaps, irrational, given my personal lack of culpability for the wrong. And the vision of decolonization that begins with states wronging people can sometimes ground this sense of personal wrongdoing as a source of shame. 
Much modern political philosophy has accepted the thesis that the motivation of shame is more powerful than the motivation of justice. Thomas Pogge's analysis of global justice, notably, began with what might be called a structural account; the rules of the world were unjust, and a shared political effort was required to rewrite them (Pogge, 1989). Pogge later rewrote this account, to emphasize the first-personal culpability of his readers in the imposition and maintenance of these rules. The citizens and leaders of the wealthy states, he wrote, were complicit in the greatest crime in human history (Pogge, 2003: 2425). The two accounts are not entirely unrelated; both rely upon the thought that the rules laid down - rules that emerge from colonial dispossession - are rules that are both unjust and susceptible of being changed by human agency. But the latter account sought to invoke something much more like shame; it's not simply that the rules are bad, but that we are bad people, for acting within and through those rules. Leif Wenar makes a similar note in Blood Oil, arguing that the purchases we make that support tyranny abroad should make us question our assumption of moral innocence:

We do fund human suffering when we make our everyday purchases, and our shopping today does incentivize injustice tomorrow. More, we have been connected to oppression and conflict, corruption and poverty, throughout our lives [...]. If you thought that there was a 10 percent chance the cocoa in your favorite chocolate had been picked by young children forced to work long hours in harsh conditions, would you still buy it? What if it were a 1 percent chance? And yet there is a much higher chance that we are bringing home products made with resources forcibly taken from some of the most violated people in the world. Our moral taint is a certainty: as we will see, we all own stolen goods (Wenar, 2017: xix-Xx).

What is the relevance of these thoughts? I am not claiming that Pogge and Wenar's analyses are necessarily correct; they may or may not be. I am pointing out simply this much: both of their theories rely implicitly upon the thought that the historical legacy of colonialism must be brought home, so to speak, before arguments against that legacy can be effective. All of us who live in a system of rules that gives us unjust advantages need to be convinced to work against those advantages; and it seems comparatively rare for people to spontaneously work against their own advantages, in the absence of some sort of personal encounter with the shame that legacy ought to produce.

I believe, however, that both of the changes discussed above - moving away from interactions, and away from states - make it harder for the shame I discuss to be brought to bear. When I am a member of a state, or a leader of that state, 
I often feel a personal sense of shame for the historic actions of that state even though I was not around for the evils my state has done, that state is an ongoing historic entity, and my role within that history gives me a personal sense of shame. The fact that you can speak to me about a particular unjust interaction, too, helps motivate the sense that this shame is mine to bear - and that, therefore, I ought to be the one to do the work of overcoming that history. All this seems more weighty, I think, than the more abstract sense that I ought to do my part in making the world just.

This phenomenon, of course, is not limited to political philosophy; it is the stuff of everyday political practice, as well. In January of 2017, Björn Höcke, of the right-wing German AfD party, attacked the German practice of taking particular responsibility for the Holocaust. Höcke argued that the way in which Germany memorialized its past - in particular, with Berlin's Memorial to the Murdered Jews of Europe - was an illegitimate effort to ascribe an eternal shame to Germany, which Germany itself ought to resist: '[Germans are] the only people in the world to plant a monument of shame in the heart of its capital [ ]. [We have the] mentality of a totally vanquished people' (Taub and Fisher, 2017). Höcke is making a point rather unlike that of Pogge and Wenar; where the latter want to harness shame for justice, Höcke wants to eliminate it. What these figures share, though, is the thought that shame is powerful. Talk of heroes and villains works, I think - especially when one is made to feel that one is complicit in villainy. Lu's vision would eliminate the search for heroes and villains, which is perhaps a good thing in complex narratives in which the search may prove difficult or impossible. But to get rid of heroes and villains might be to get rid of a very powerful tool indeed. Höcke's speech provoked outrage, and rightly so. But the outrage here depends upon the thought that one should sometimes keep the fires of shame - of particular responsibility, even for histories quite far in the past - burning bright.

\section{Equity: Responsibility and Power}

This leads me to my second worry: that of equity. I am in agreement with Lu that the search for villains and heroes is often both fruitless and counterproductive. But I am also worried that a refusal to ground duties in particular acts of wrongdoing might end up allocating current burdens in wrongful ways. This worry is, of course, not wholly unrelated to the first worry. That worry dealt with how shame might be useful in producing moral motivation. This worry also looks to the past, and shame - but looks instead to whether or not that shame is perhaps relevant to figuring out how to allocate duties, here and now.

Here's an example. Imagine a colonial state that was one of the worst offenders against human dignity during the colonial period. It brutalized 
and killed on a much grander scale than its competitors. After the end of colonialism, that state decayed in power, to the point that it is barely better off now than those it colonized. Indeed, it has barely any power now to alter the structure of international law, in comparison with its slightly less vicious competitors who have now become more powerful. Lu's vision would say that the duty to overcome the legacy of colonialism should be viewed as - I take it - something like a shared project amongst all stakeholders; those who can do the most to make the world right, should do the most. But I can't shake the feeling that the vicious colonial state has a particular duty to make the world right - even if it has comparatively less power with which to do so. Even if that state's leadership wasn't there to be responsible for the atrocities, they can take responsibility now - in a manner that reflects a sense that this state, in particular, is the inheritor of that particular moral stain. The state that did evil is the state that has a particular duty to overcome that evil. I am worried that Lu's move towards structural injustice might rob us of the language we need to make sense of these particularistic duties. I am further worried that her move away from statism might make it too easy for states to escape from such duties; and states, to put it simply, are historic entities that are uniquely positioned to understand themselves as bearing responsibility for what they did.

Here, too, the examples are not merely hypothetical. Take, for instance, Belgian colonialism in Africa. Belgian colonists were unusual, even in the context of colonial brutality, for their cruelty (Hochschild, 1998.) Belgium has, since the 19th century, fallen somewhat in international power; it is still wealthy, but less central a player in international politics. And yet it might be thought that Belgium has, even relative to its diminished fortunes, a greater duty than other states to work for the undermining of colonial privilege. The German monuments decried by Höcke at least exist; Germany continues to regard itself as under a particular duty to overcome the legacy of the Holocaust. And yet, as recently as 2003, no monuments to those killed in Belgian colonialism could be found in Brussels. Instead, a visitor to the Museum for Central Africa could find an institution arguing that Belgium provided both 'security' and 'well-being' to the Africans it worked to death (Winneker, 2003).

Lu acknowledges these concerns as regards a duty of acknowledgment ( $\mathrm{Lu}$, 2017: 180); Belgium, Lu and I would agree, is failing even this duty. I am simply worried that this concession isn't quite enough. Monuments are useful, and their absence is sometimes indicative of an illegitimate desire to forget one's past. What's needed, though, is the shared will to do what's needed here and now to make the world new. In the allocation of this duty, though, I think the refusal to regard states as having particular duties - to bear more than other states, 
because of what the particular state has done - seems to be an important part of the story. The modern state may not be in a position to adequately respond to the evils in its history; but it might be only fair for it to regard itself as uniquely obligated to try.

I would reiterate that there is nothing in what I say that should be interpreted as a reason to reject Lu's vision of international justice. Lu's vision is powerful, and attractive. What I write here is intended only to figure out what makes me hesitate about signing on to her vision. At its heart, I worry that a structural view of injustice might rob us of the tools we need to make people do - if not what's right, then at least some halting steps towards what's right. What is no-one's fault, I think, is too often no-one's burden to put right. A statist and transactional view of colonial injustice will have many faults - but it provides us with some tools with which to motivate agency against colonialism. As the modern world becomes more and more unwilling to listen to the dictates of reason, I worry we might need to be careful before those tools are abandoned. ${ }^{1}$

\author{
Michael Blake \\ Professor of Philosophy in Public Policy, \\ and Governance \\ Department of Philosophy \\ University of Washington \\ email:miblake@uw.edu
}

\title{
- the globaljusticenetwork
}

1 I would like to express gratitude to my fellow panelists at the International Studies Association panel on Catherine Lu's book - and, most importantly, to Catherine Lu and to Christine Straehle, for this conversation and for many others besides. 


\section{Bibliography}

Hocschild A (1998) King Leopold's Ghost: A Story of Greed, Terror, and Heroism in Colonial Africa. New York: Mariner Press.

Lu C (2017) Justice and Reconciliation in World Politics. Cambridge: Cambridge University Press.

Pogge T (1989) Realizing Rawls. Ithaca: Cornell University Pres.

Pogge T (2002) World Poverty and Human Rights. London: Polity Press.

Taub A and Fisher A (2017) Germany's Extreme Right Challenges Guilt Over Nazi Past. The New York Times. Available at: https://www.nytimes.com/2017/01/18/world/europe/germany-afdalternative-bjorn-hocke.html (accessed: 4 July 2019).

Wenar L (2017) Blood Oil: Tyrants, Violence, and the Rules that Run the World. New York: Oxford University Press.

Winneker C (2003) A Perfect Specimen of Colonial Mythmaking. Washington Post, August 10, 2003. Available at: https://www.washingtonpost.com/archive/opinions/2003/o8/10/aperfect-specimen-of-colonial-mythmaking/f933059e-fb9a-4bdb-9d18-c8b26f56a8a4/?utm _ term $=.46 \mathrm{e} 561492 \mathrm{~b} 72$ (accessed: 4 July 2019). 